\title{
Foam spora in running waters of southern Greenland
}

\author{
EVA ENGBLOM, PER-ERIK LINGDELL, LUDMILA MARVANOVÁ AND AGNES MÜLLER-HAECKEL
}

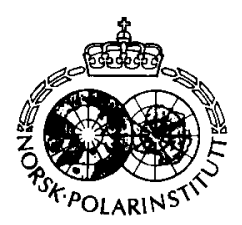

\begin{abstract}
Engblom, E., Lingdell, P.-E., Marvanová, L. \& Müller-Haeckel, A. 1986: Foam spora in running waters of southern Greenland. Polar Research 4 n.s., 47-51.

Nineteen species of aquatic hyphomycetes are reported from stream foam in southern Greenland. This extends the number of species known from the arctic regions. Thirteen of these species have also been collected in Swedish Lapland. Thus, despite different bank vegetation, the species pattern of both areas show a more than $50 \%$ similarity.

Eva Engblom and Per-Erik Lingdell, Myggdalsvägen 120, 13543 Tyresö, Sweden; Ludmila Marvanová, Czechoslovak Collection of Microorganisms, J. E. Purkyne University, Brno, Czechoslovakia; Agnes Müller-Haeckel, Department of Animal Ecology, University of Umed, Sweden; February 1985 (revised November 1985).
\end{abstract}

Previous accounts (Müller-Haeckel \& Marvanová 1977, 1979; Marvanová \& Müller-Haeckel 1980) show that subarctic waters may contain large amounts of aquatic and water-borne hyphomycete conidia and also that the diversity of the species is relatively high. The localities investigated (Messaure, Abisko) are in Boreal coniferous forests, and the main deciduous trees on the banks of the streams are Betula pendular, Populus tremula, Alnus glutinosa, Salix caprea, S. spp., and Sorbus aucuparia.

Greenland, as a whole, is considered to be arctic while the vegetation in the ice-free coastal areas is tundra. Several mycological investigations have been carried out there in the past, mainly on the west of the island ( for a survey, see Kobayasi et al. 1971). In 1968, during a mycological exploration of the Angmagssalik region (Kong Christian IX's Land, $65^{\circ} 39^{\prime} \mathrm{N}$; see Fig. 1), three foam samples yielded six species of aquatic hyphomycetes; two further species were isolated from soil samples (Kobayasi et al. 1971).

\section{Material and methods}

The present study is the result of an investigation of Greenland, in the region of Narssaq near Julianehåb (Kong Frederik VI's kyst, between $60^{\circ} 50^{\prime}$ and $61^{\circ} 15^{\prime} \mathrm{N}$, Fig. 1). The prevailing tree- and shrub-vegetation comprises Betula glandulosa, $B$. pubescens, Sorbus decora spp. groenlandica, Salix arctophila, S. glauca, S. glauca spp. callicarpea, $S$. uva-ursi, S. herbacea, Juniperus communis, Ledum groenlandicum, Cassiope tetragona, Empetrum hermaphroditum, Phyllodoce coerulea, and Vaccinium uliginosum var. microphyllum.
The sampling sites are shown in Fig. 1. A brief characterization of the eight streams follows:

1. Stony banks with low shrub-vegetation, grasses and mosses. The stream has its source in a flat landscape (grassland, moorland, natural and cultivated pastures).

2. Stony banks with low shrub-vegetation and grasses. The stream has its source in the hills.

3. Stony banks with grasses and mosses and scattered shrubs; a considerable amount of filamentous green algae in the water. The stream originates in a lake with banks lined with low shrubs, grasses and some dicotyledonous plants.

4. Stony banks with grasses and herbs (Ranunculus sp.); occasionally willow shrubs.

5. Banks densely covered with willow shrubs; scattered Sedum rosea.

6. The stream has cut deeply into a flat landscape; the banks are stony with grasses and low shrubs. It has its source in hills.

7. Hilly landscape; banks covered with grasses and shrubs.

8. Banks with dense vegetation of shrubs, grasses and herbs as Campanula rotundifolia, Chamaenerion angustifolium, Rumex acetosa, Saxifraga aizoides, S. adscendens, Sedum annuum, Taraxacum sp.

Foam could be collected in nine of the 31 investigated streams, and eight of the samples contained conidia of aquatic hyphomycetes. Some further ecological characteristics of the sampling sites are shown in Table 1. The foam samples were fixed with concentrated potassium-iodine solution on the spot and examined after several weeks. 


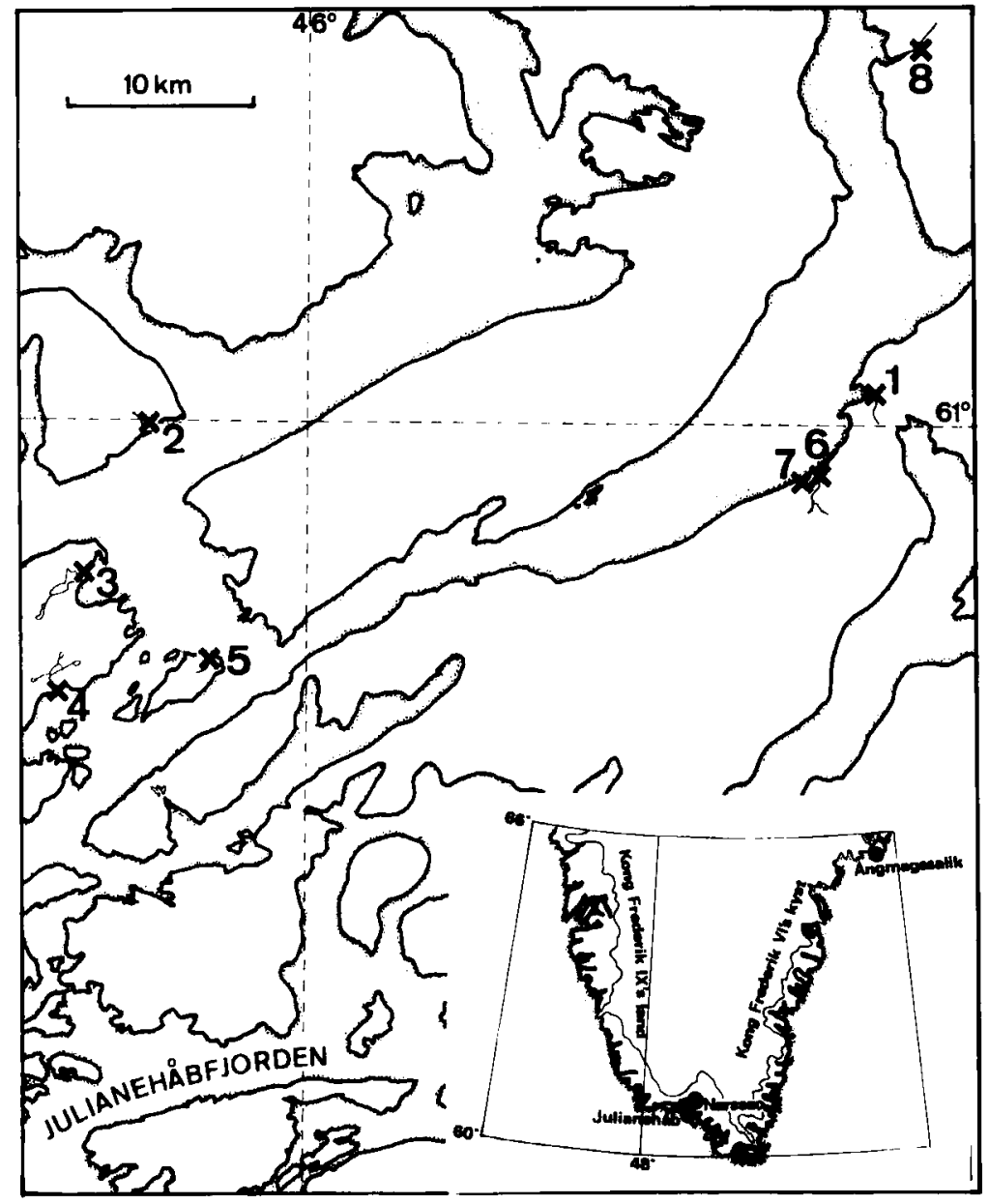

Fig. 1. Map with cight sampling sites in the vicinity of Narssaq and a survcy of southern Greenland showing the geographical situation of Angmagssalik and Narssaq.

Table 1. Survey of localities.

\begin{tabular}{llllll}
\hline Site & Date of sampling & Water temperature & pH & Max. strcam width & Max. strcam depth \\
\hline 1. & 5 July 1979 & $15^{\circ} \mathrm{C}$ & 7.2 & $2 \mathrm{~m}$ & $0.5 \mathrm{~m}$ \\
2. & 18 July 1979 & $11^{\circ} \mathrm{C}$ & 7.1 & $2 \mathrm{~m}$ & $0.5 \mathrm{~m}$ \\
3. & 20 July 1979 & $12^{\circ} \mathrm{C}$ & 7.3 & $2 \mathrm{~m}$ & $0.7 \mathrm{~m}$ \\
4. & 21 July 1979 & $8^{\circ} \mathrm{C}$ & 6.1 & $1 \mathrm{~m}$ & $0.3 \mathrm{~m}$ \\
5. & 23 July 1979 & $6^{\circ} \mathrm{C}$ & 5.8 & $3 \mathrm{~m}$ & $0.7 \mathrm{~m}$ \\
6. & 27 July 1979 & $9^{\circ} \mathrm{C}$ & 6.9 & $8 \mathrm{~m}$ & $0.4 \mathrm{~m}$ \\
7. & 27 July 1979 & $6^{\circ} \mathrm{C}$ & 7.1 & $1 \mathrm{~m}$ & $0.5 \mathrm{~m}$ \\
8. & 31 July 1979 & $8^{\circ} \mathrm{C}$ & 7.0 & $1 \mathrm{~m}$ & $0.3 \mathrm{~m}$ \\
\hline
\end{tabular}

\section{Results and discussion}

The list of hyphomycete species and their distribution in the localities is shown in Table 2. Rare conidia and unidentified spores are depicted in Fig. 2.
A total of 19 species were identified; two spore types could be classified with some reservation, while six remained unidentified. The largest numbers of species were found in locality Nos. 2 (12 spp.) and 6 (11 spp.). Both streams originate in hills. Alatospora acuminata, Articulospora tetra- 
Fig. 2. Conidia and spores from foam in southern Greenland. a. Heliscella stellatacular-like conidia; b, c. unidentified: d. Dwayaangam cornuta; c. unidentificd: f. Tricladium curvisporum; g. Dendrospora sp.: h. unidentified, dematiaceous; i. j. unidentified; k. Alatospora pulchella (as secn in samples from $1,5,6 ; b, c, c, g, h, i, j$ in sample from sitc 6). Scalc $=50 \mu \mathrm{m}$.

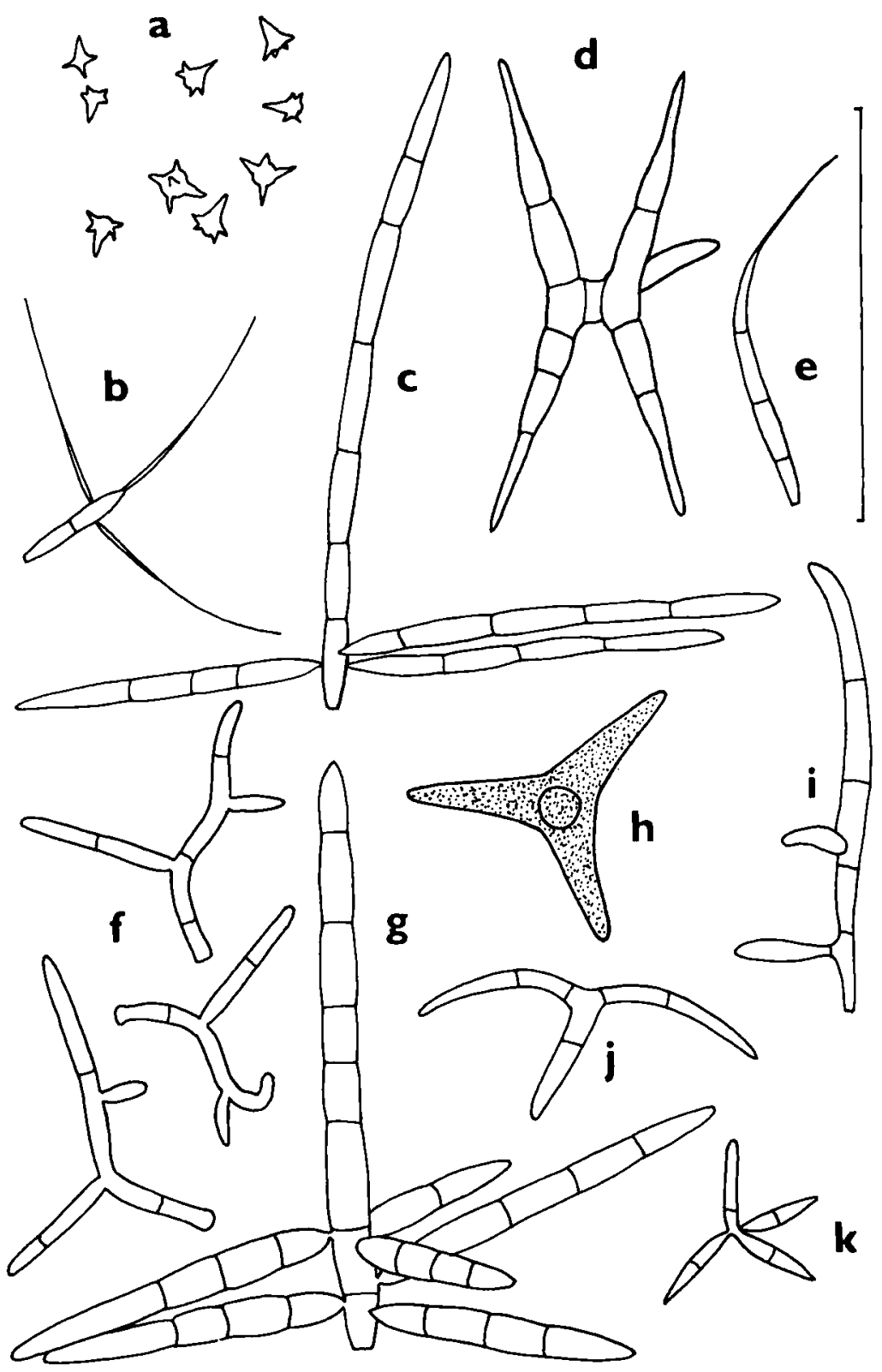

cladia, and Varicosporium elodeae belong to the more frequently observed species found in at least six localities. In comparison to a stream in Abisko/Sweden (Marvanová \& Müller-Haeckel 1980) with 20 species and 21 unidentified spore types, the hyphomycete flora in Greenland is similar; 13 species found in the samples from Greenland were present even in the stream near Abisko.

\section{Remarks on species}

Alatospora acuminata Ingold is a very variable species (Marvanová \& Descals 1985); in our samples we found conidia with broad as well as narrow insertion of branches.

Anguillospora crassa Ingold. Conidia seen in sample No. 6 were typical of the shape and size depicted by Ingold (1958). 
Table 2. List of hyphomycete species found in southern Greenland.

\begin{tabular}{|c|c|c|c|c|c|c|c|c|}
\hline & 1 & 2 & 3 & 4 & 5 & 6 & 7 & 8 \\
\hline Alatospora acuminata Ingold & $x$ & $x$ & & & $x$ & $x$ & & $x$ \\
\hline Alatospora pulchella Marvanová & & & & & $x$ & $x$ & & \\
\hline Anguillospora crassa Ingold & & & & & & $x$ & & \\
\hline Articulospora tetracladia Ingold & $x$ & $x$ & $x$ & & $x$ & $x$ & & $x$ \\
\hline Clavatospora longibrachiata (Ingold) Marvanová et S. Nilsson & & $x$ & & & $x$ & & & \\
\hline Dwayaangam cornuta Descals & & & & & & $\times$ & & \\
\hline Heliscella stellata (Ingold et Cox) Marvanová et S. Nilsson & & $x$ & & & $x$ & & & \\
\hline Heliscus lugdunensis Sacc. et Therry & $x$ & $x$ & & & & $x$ & & $x$ \\
\hline Geniculospora inflata (Ingold) Marvanová et S. Nilsson & $x$ & $x$ & & & & & & \\
\hline Lemonniera centrosphaera Marvanová & & $x$ & & & & & & \\
\hline Lemonniera terrestris Tubaki & & $x$ & $x$ & & & & $x$ & \\
\hline Mycocentrospora acerina (Hartig) Deighton & $x$ & $x$ & & & & $x$ & & \\
\hline Pleuropedium tricladioides Marvanová et Iqbal & $x$ & $x$ & & & & & & \\
\hline Taeniospora gracilis Marvanová & & $x$ & & & & $\times$ & & \\
\hline Tetracladium maxilliforme (Rostrup) Ingold & & & & & & & $x$ & \\
\hline Tricladium curvisporum Descals & & & & & & $x$ & & \\
\hline Tricladium eccentricum $\mathbf{R}$. H. Petersen & $x$ & & & & $x$ & & & \\
\hline Varicosporium elodeae Kegel & $x$ & $x$ & & $x$ & $x$ & $x$ & & $x$ \\
\hline Volucrispora graminea Ingold et al. & & & & & & $x$ & & \\
\hline Number of species & 8 & 12 & 2 & 1 & 7 & 11 & 2 & 4 \\
\hline
\end{tabular}

Dwayaangam cornuta Descals is an easily recognizable species because of the striking configuration of its conidia. Besides several records from Great Britain (Descals \& Webster 1982), it has been reported or illustrated as unknown from several other European countries, mostly from mountain streams: German Democratic Republic (Arnold 1968; Marvanová 1984a), Czechoslovakia (Marvanová 1984b), Hungary (Gönczöl 1971; Gönczöl \& Tóth 1974), Romania (Tóth 1973), France (Lorillard 1973), and Spain (Descals et al. 1977). Probably the same species was depicted also from tropical and subtropical countries: Nigeria (Ingold 1959), Jamaica (Hudson \& Ingold 1960).

Dendrospora sp. (Fig. 2g) is similar to Dendrospora fusca Descals \& Webster (1980) described from Great Britain. However, the ends of the conidial elements taper more in the Greenland material and the conidium has a slightly different habit. Tubaki in Kobayasi et al. (1971) illustrates a Dendrospora from Greenland which may be Dendrospora fusca.

Heliscella stellatacula-like conidia (Fig. 2a) were found in three samples. They were fairly different from those of Heliscella stellata, in one case present in the same sample, as they were smaller, mostly five-pronged, with a thick conidial body and relatively abruptly attenuated processes. However, since such shapes are encountered in cuitures of Heliscella stellata, too, this may hinder identification without cultivation. Heliscella stellatacula (Kirk) Marvanová has a different ecology (estuary, c. $39^{\circ} \mathrm{N}$; Kirk 1969). However, Marvanová (1980), working with an authentic isolate (ATCC 18573), found longer and more profuse sporulation in distilled water than in artificial sea water of 35\% salinity. Jones (1972) reports this species on beach wood blocks in a freshwater habitat without further details.

Pleuropedium tricladioides Marvanová et Iqbal is being split into two species (Marvanová \& Descals, unpublished). The conidia seen in the Greenland localities had longer elements (axis 59-64 $\mu \mathrm{m}$, primary lateral $47-53 \mu \mathrm{m}$, secondary lateral 33-36 $\mu \mathrm{m}$ ) with numerous septa.

Taeniospora gracilis Marvanová. Conidia reported here belong to a new variety the descrip- 
tion of which is in preparation (Marvanová \& Staplers, unpublished). They differ from the genuine type by their more or less cylindrical axis with a foot-shaped base and by their broad insertion of branches.

Tetracladium maxilliforme (Rostrup) Ingold has conidia similar to Tetracladium furcatum Descals; the conidia seen by us consisted of a short stalk with a rounded base, bearing two parallel fingerlike outgrowths each with a setose extension on the outer side. This matches the present concept of this species as understood by Ingold (1942).

Tricladium curvisporum Descals (Fig. 2f), a recently described taxon from Great Britain (Descals \& Webster 1983), is also known from Czechoslovakia (Marvanová 1984b). The relatively small conidia are recognizable by their sigmoid axis with a truncate or even slightly inflated base, and branches with a slightly narrowed insertion.

Of the species reported from the waters of Greenland in Kobayasi et al. (1971), only Articulospora tetracladia and Varicosporium elodeae could be found in our samples. The species reported as Anguillospora longissima (Sacc. et Syd.) Ingold is, according to the given size, probably another taxon.

The relatively high number of species (19) found in the waters of Greenland, added to those in the stream near Abisko (20) (Marvanová \& Müller-Haeckel 1980), considerably extends the northern limit of distribution of these fungi. This may probably be caused by the somewhat moderating effect of the water environment, where the temperature and other conditions do not change as strongly and suddenly as they do in terrestrial niches. In this connection, it may be of interest to check for possible telemorphs (perfect states) of aquatic hyphomycetes found in the high north. Up to now, these are only reported from temperate and tropical regions.

There are several unnamed collections of Hymenoscyphus Gray and Mollisia (Fr.) P. Karsten described in Kobayasi et al. (1971), but an attempt to identify them as telemorphs of $A n$ guillospora crassa, Articulospora tetracladia and Tricladium splendens, all of which occur in arctic and subarctic waters, failed.

\section{References}

Arnold, G. R. W. 1968: Sporen aquatischer Hyphomyceten aus Gewässern im Bezirk Halle. Wiss. Zeitschr. Friedrich-Schiller Universität Jena, Math. -Naturwiss. Reihe 17, 369-373.

Descals, E., Sanders, P. F. \& Ugalde, U. O. 1977: Hifomicetos ingoldianos del Pais Vasco. Munibe (Sociedad de Ciencias Naturales Aranzadi, San Sebastián, Spain) 29, 237-260.

Descals, E. \& Webster, J. 1980: Taxonomic studies on aquatic hyphomycetes. II. The Dendrospora aggregate. Trans. Br. Mycol. Soc. 74, 135-158.

Descals, E. \& Webster, J. 1982: Taxonomic studies on aquatic hyphomycetes. III. Some new species and a new combination. Trans. Br. Mycol. Soc. 78, 405-437.

Descals, E \& Webster, J. 1983: Four new staurosporous hyphomycetes from mountain streams. Trans. Br. Mycol. Soc. 80 , $67-75$.

Gönczöl, J. 1971: Aquatic Hyphomycetes from the Mts. Börzsöny. Ann. Hist.-Nat. Mus. Nat. Hung. 63, 57-75.

Gönczöl, J. \& Tóth, S. 1974: Rare or interesting conidia from streams in Hungary. Bot. Közlem. 61, 25-35.

Hudson, H. J. \& Ingold, C. T. 1960: Aquatic hyphomycetes from Jamaica. Trans. Br. Mycol. Soc. 43, 469-478.

Ingold, C. T. 1942: Aquatic hyphomycetes of decaying alder leaves. Trans. Br. Mycol. Soc. 25, 339-417.

Ingold, C. T. 1958: New aquatic hyphomycetes: Lemonniera brachycladia, Anguillospora crassa and Fluminispora ovalis. Trans. Br. Mycol. Soc. 41, 365-372.

Ingold, C. T. 1959: Aquatic spora of Omo forest, Nigeria. Trans. Br. Mycol. Soc. 42, 479-485.

Jones, E. B. G. 1972: The decay of timber in aquatic environments. In: British Wood Preserving Association, Annual Convention, 1-18

Kirk, P. W. Jr. 1969: Aquatic hyphomycetes on wood in an estuary. Mycologia 61, 177-181.

Kobayasi, Y., Hiratsuka, N., Otani, Y., Tubaki, K., Udagawa, S., Sugiyama, J. \& Konno, K. 1971: Mycological studies of the Angmagssalik region of Greenland. Bull. Nat. Sci. Mus. Tokyo, 14, 1-96.

Lorillard, M. 1973: Hyphomycètes aquatiques de la région de Pau. Bull. Soc, Hist. Nat. Toulouse 109, 251-256.

Marvanová, L. 1980: New or noteworthy aquatic hyphomycetes. Clavatospora, Heliscella, Nawawia and Heliscina. Trans. Br. Mycol. Soc. 75, 221-231.

Marvanová, L. 1984a: Notes on water-borne micromycetes in northern parts of the German Democratic Republic. Feddes Repertorium (Berlin) 95, 201-207.

Marvanová, L. 1984b: Conidia in waters of the protected area Slovenský raj. Biológia (Bratislava) 39, 821-832.

Marvanová, L. \& Descals, E. 1985: New and critical taxa of aquatic hyphomycetes. Bot. J. Linnean Soc. 91.

Marvanová, L. \& Müller-Haeckel, A. 1980: Water-borne spores in foam in a subarctic stream system in Sweden. Sydowia, Ann. Mycol. 33, 210-220.

Müller-Haeckel, A. \& Marvanová, L. 1977: Konidienproduction und -kolonisation von Süsswasser-Hyphomyceten im Kaltisjokk (Lappland), Bot. Notiser 129, 405-409.

Müller-Haeckel, A. \& Marvanová, L. 1979: Periodicity of aquatic hyphomycetes in the subarctic region. Trans. Br. Mycol. Soc. 73, 109-116.

Toth, S. 1973: Aquatic hyphomycetes from Transylvania. Bot. Közlem. 60, 153-156. 